\title{
Epidemiology and Biochemical Effects of Brucellosis in Kafer-EI Sheikh and Qualyobia Cow's Farms
}

\author{
Halla E .k. El Bahgy ${ }^{1}$ and Abdel-Fatah $\mathrm{Ali}^{2}$ \\ ${ }^{1}$ Animal Hygiene, Behavior and Management Department, Faculty of Veterinary Medicine, Benha University, \\ Egypt. ${ }^{2}$ Department of Clinical Pathology, Faculty of Veterinary Medicine, Benha University, Egypt
}

\begin{abstract}
This study was conducted to determine seroprevalence of brucella infection in cows in Kafer ElSheikh and Qualyobia governorates and evaluate the biochemical parameters of infected cows that reflect the effects of brucella infection on animal health and performance. A total of 240 blood samples were collected from cows (120 from kafr-El Shick and 120 from Qualyobia). All sera were tested by Rose Bengal Plate Test (RBPT), Buffered acidified Plate Antigen Test (BAPAT) and Complement Fixation test (CFT). Brucellosis antibodies were detected in 18 of $120(15 \%)$ and 6 of $120(5 \%)$ cattle serum samples collected from Kafr-El Shick and Qualyobia governorates respectively. There was a significant correlation between brucellosis antibodies in cattle serum samples and location where the blood samples be collected. The highest prevalence of brucellosis antibodies was detected in cattle serum samples > 6 years of age in two governorates. Biochemical examinations revealed significant increase in Alanine aminotransferase (ALT), Aspartate aminotransferase (AST), Creatinine kinase (CK) and cholesterol levels in serum of Brucella infected cows in comparison with healthy cows. Meanwhile no significant changes were reported in urea, creatinine, glucose and C-reactive protein (CRP) levels. Changes in biochemical parameters reveled that brucellosis has harmful effects on cow's health. It could be concluded that determination of biochemical parameters in cow can determine the extent of damage caused by brucella infection.
\end{abstract}

Keywords: Brucellosis, Biochemical Examinations, Epidemiology.

\section{Introduction}

Brucellosis, caused by Brucella species, is a chronic zoonotic disease which is facultative anaerobic non-motile intracellular bacteria and Gram-negative [1]. The species of Brucella are Br. abortus in cattle as major host, Br. Melitensis in goats, Br. suis in swine and Br. ovis in sheep. Br. abortus also causes infection in horses and is commonly found as a secondary invader rather than a primary pathogen in chronic bursal enlargements [2].Brucellosis is a widespread and highly infectious disease, with a great economical impact on cattle farming [3]. Bovine brucellosis is usually caused by Brucella abortus. It is characterized by abortion, with excretion of the organisms in uterine discharge and milk. Major economic losses result from abortion. Loss of calves, reduced milk yield in females and infertility in males[4]. It is also well known that animal infected with Brucella species contaminate the environment and play an important role in the spread of these infections to other susceptible animals. Moreover, these infections are zoonotic and populations such as farm workers, abattoir workers, veterinary surgeons and shepherds are also at risk of these infections. Therefore, it is essential to conduct serological tests to detect carriers and keep the flocks free of the infections [5].

Brucella infection transmitted to human through the contact with the infected materials or consumption of contaminated raw milk and milk products due to traditional feeding habits [6]. Eradication of brucellosis in animals is a required step to control the human diseases [7]. Although, brucellosis has been successfully eradicated in some countries but it is still endemic in many regions of the world [8]. In Egypt, the brucellosis was reported for the first time in 1939 for and is now endemic in some governorates of the country [9].

Diagnosis of brucellosis not basic on abortion only due to it equivocal since many pathogens can induce abortion; thus laboratory testing is essential [10]. Brucellosis is not having specific symptoms so the clinical diagnosis of the disease is difficult. Therefore the diagnosis must be supported and confirmed by the detection of antibodies against bacterial antigens, or by the isolation of the agent mostly from blood culture [11] and [12]. Some serological methods are easy to perform and can be used in the field itself. Rose Bengal Plate Test (RBPT) is one of them used to screen the flocks as a spot agglutination test. The test is highly sensitive for individual diagnosis and can be performed in the field. The RBPT can be applied in all animal species serum samples but should be confirmed the positive results by a quantitative test [13]. BAPAT and RBPT serological tests revealed the highest rate of sensitivity that guide us to use these tests as screening tests on animals brucellosis.

Brucellosis have serious effects on animal health because it infect vital organs in the body such as heart, liver, kidney and muscle leading to impairment of their function through increase or decrease the released enzymes according to the stage of infection and their damage, [14], [15] and [16]. These changes in blood 
metabolites can be used as indicators for the infection and consequently help in their diagnosis [17].There are so many factors that can affect the prevalence of brucellosis in various species of livestock so, the prevalence of brucellosis may vary with time even in the same region [18]. Prevalence of brucellosis can vary according to climatic conditions, geography, species, sex, age and diagnostic tests applied.

The aims of this work are to determine seroprevalence of brucella infection in cows in Kafer El- Shick and Qualyobia governorates and to evaluate the biochemical parameters of infected cows that reflect the effects of brucella infection on animal health and performance.

\section{II. .1. Retrospective study:}

\section{Material and methods}

Data on brucellosis disease outbreaks which occurred at 2010 to 2016 in Egypt mainly Kafr- El Shick and Qualyobia governorates were collected from World Organization of Animal Health at its web site [19].

\section{II. .2. Sampling:}

The blood samples were collection from two different farms according to type of housing and location of farms. A total number of 240 blood samples were collected from cows including apparent health and aborted animals (120 from kafr- El Shick farm with parlour and loose house system and 120 from Qualyobia farms with cow house system). The studied animals varied in age and breed.

Ten $\mathrm{ml}$ of blood samples were collected from the jugular vein of each animal and samples transported on ice to the laboratory of Animal Hygiene, Behavior and Management Department, Faculty of Veterinary Medicine, Benha University. The blood samples were left in tightly closed tubes overnight at $4^{\circ} \mathrm{C}$, and then centrifuged at $3000 \mathrm{rpm}$ for 10 minutes to separate the sera. The clear serum was obtained by using sterile Pasteur pipettes and placed in Eppendorff tubes, labeled and stored at $-70^{\circ} \mathrm{C}$.

\section{3. Site of sampling:}

The samples were collected from cows at different localities and housing system. Kafr- El Shick cow farm was had high hygienic condition including continuous evacuation of manure, burning of litter and good disinfection program for farms and vehicles, while Qualyobia farm was had bad hygienic conditions. Kafr- El Shick cows farm was closely located to sheep farms.

\section{4. Serological tests:}

The collected blood samples were tested for brucella antibodies using serological tests according to [19]. All sera were tested by RBPT, BAPAT and CFT was performed as described in the manual of standards for diagnostic tests and vaccines. Brucella seropositive cows were designated as those with both a positive screening tests and CFT results.

\section{4.1. Rose Bengal Plate Test (RBPT):}

This test was done according to [20].The brucella abortus antigen for RBPT is an $8 \%$ Rose Bengal stained $\mathrm{Br}$. abortus strain 99 cells in lactate buffer $\mathrm{PH}(3.65 \pm 0.05)$.

\section{II.4.2. Buffered acidified Plate Antigen Test (BAPAT):}

This test was carried out according to [21].The brucella abortus antigen for BAPAT is a crystal violet brilliant green strain $\mathrm{Br}$. abortus strain 99 cells at concentration of $11 \%$ in lactate buffer $\mathrm{PH}(4.02 \pm 0.04)$.

\section{II.4.3. Complement Fixation Test (CFT):}

This test was done according to [22].USDA'S standard tube tests concentrate $(4.5 \% \mathrm{Br}$. abortus biovar 1 strain 1119-3 cells in phenol salinelfinal PH 6.8). It was kindly offered by the National Veterinary Service Laboratories (NVSL), Ames, USA.

\section{II.5. Biochemical analysis:}

ALT and AST were determined spectrophotometrically according to [23]. Creatinine was determined spectrophotometrically according to [24].Urea was determined spectrophotometrically according to [25]. Glucose was determined by enzymatic-colorimetric method according to [26]. Cholesterol was determined by enzymatic colourimeteric method according to [27]. Creatinine kinase (CK) was determined according to the method described by [28]. C-reactive protein (CRP) was determined according to [29].

\section{6. Statistical analysis:}

The statistical analyses were done by Univariate Analysis of Variance, one way ANOVA and Independent $t$ tests using SPSS program version 20. $P$ value $<0.05$ was assumed for statistical significance. 


\section{Results}

Surveillance was conducted to investigate the sero-pervalence of Brucellosis in susceptible animals' cattle sampled from Kafr- El Shick and Qualyobia governorates. Antibodies were detected using RBPT, BAPAT and CFT. Results are illustrated in table (1-4) and chart (1-3). The results of the serum biochemical parameters determination are presented in table (5).

Brucellosis antibodies were detected in 18 of $120(15 \%)$ and 6 of $120(5 \%)$ cattle serum samples collected from Kafr-El Shick and Qualyobia governorates respectively (Table 1). There was a significant correlation between brucellosis antibodies in cattle serum samples and location where the blood samples were collected (Table 2). The highest prevalence of brucellosis antibodies was detected in cattle serum samples $>6$ years of age in two governorates (Table 3). Brucella seroprevalence was significantly higher in adult cattle than in young one ( $\mathrm{p}$ <.05) (Table 4). Biochemically, It was observed that serum ALT, AST and CK activities and cholesterol level showed significant increase $(\mathrm{p}<0.05)$ in Brucella infected cows when compared with healthy cows. However, serum CRP, BUN, creatinine and glucose levels did not show much variation between brucella infected and healthy cows table (5).

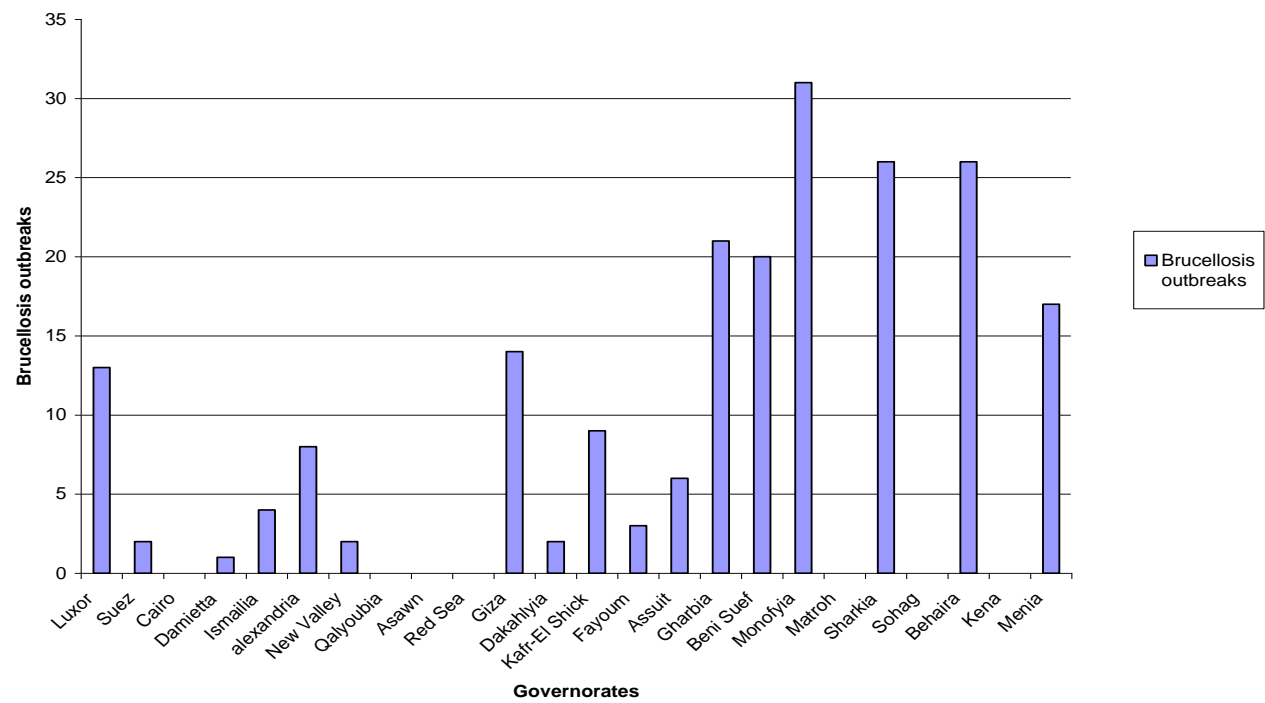

Chart (1): Brucellosis outbreaks in Egypt during year 2015.

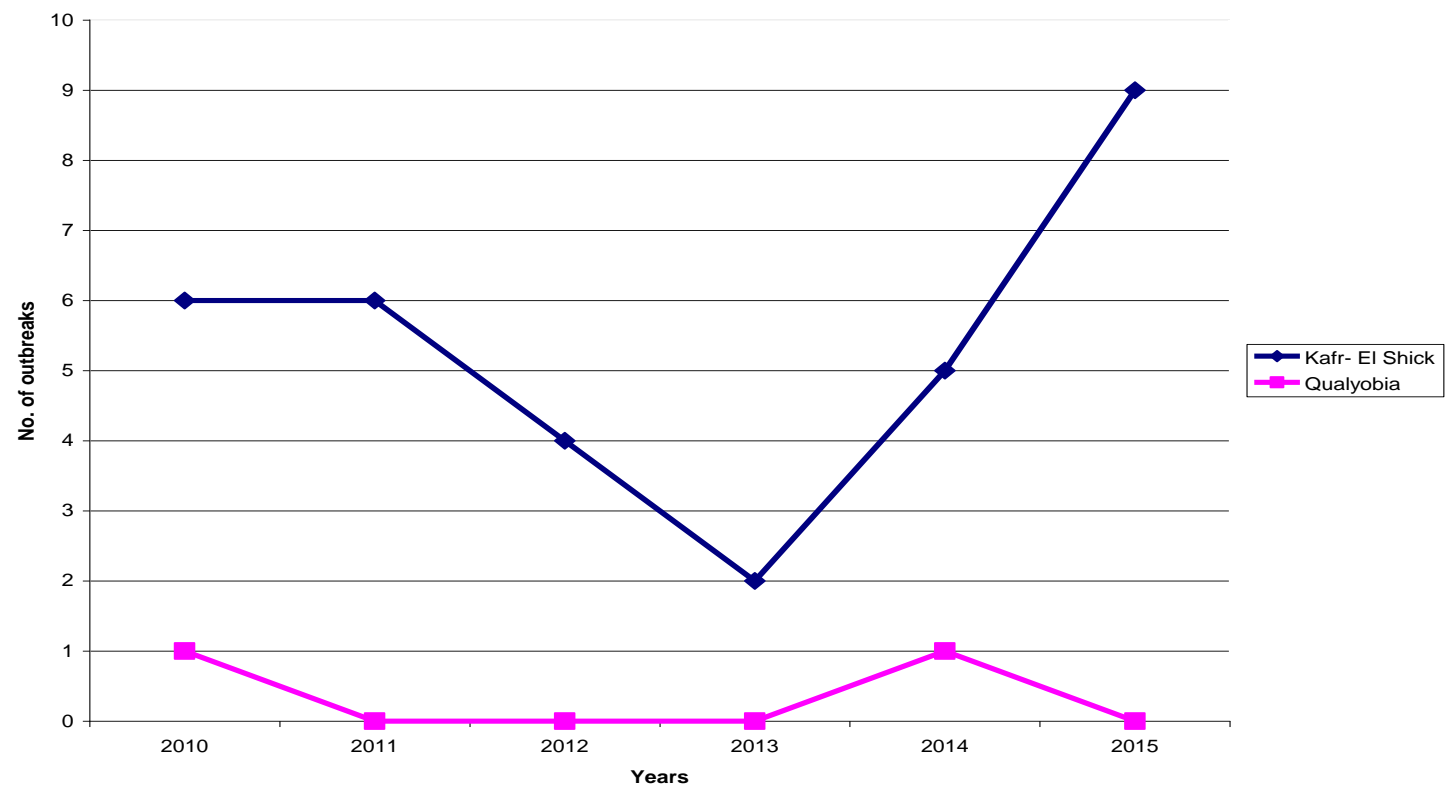

Chart (2): Brucellosis outbreaks in Kafr- El Shick and Qualyobia governorates during last 6 years. 


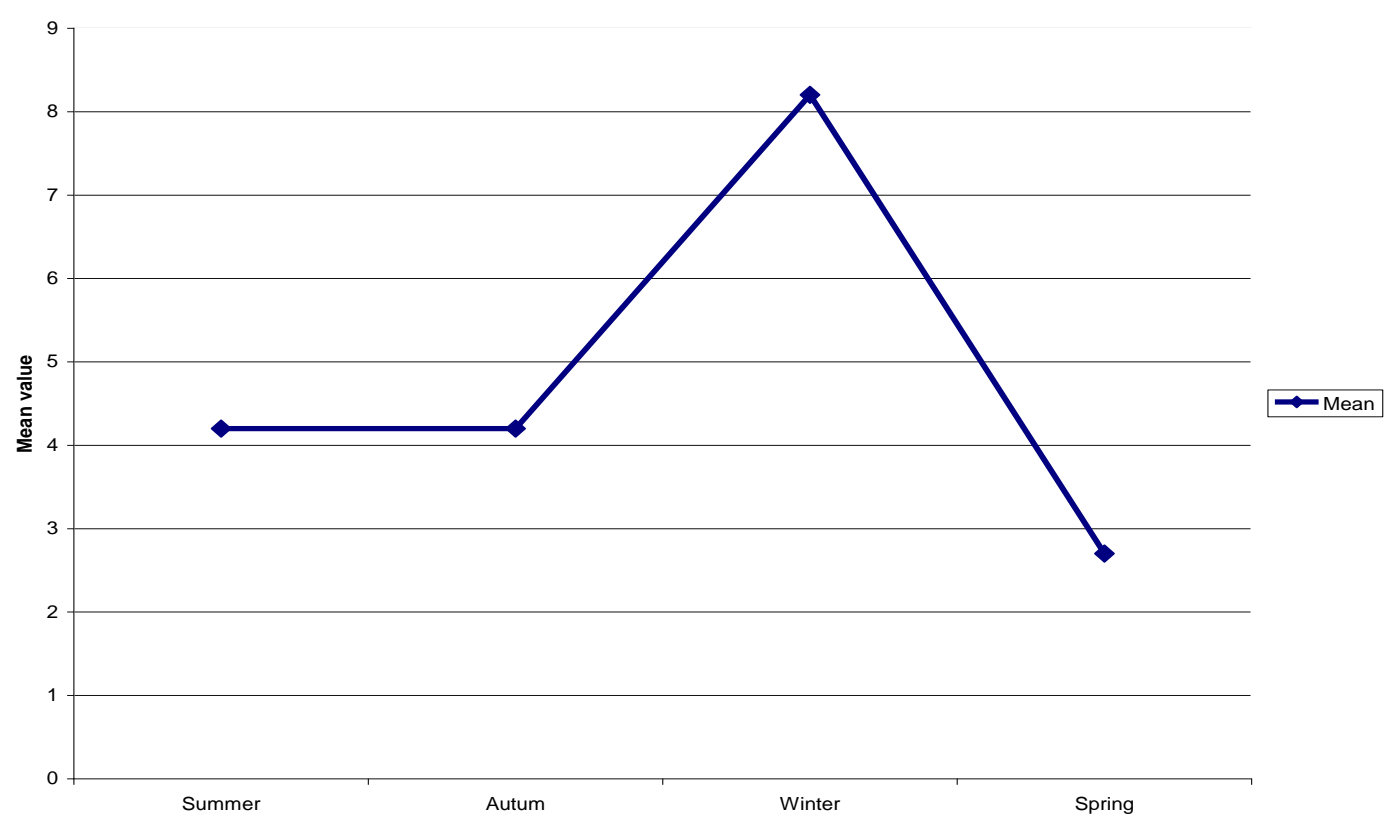

Chart (3): Mean value of brucellosis cases during seasons of last 6 years in kafr El Shick and Qualyobia.

Table (1): Seroprevallence of brucellosis among cattle serum samples at Kafr- EL Shick and Qualyobia farms

\begin{tabular}{|l|c|c|c|}
\hline \multicolumn{1}{|c|}{ Governorates } & No. of samples & No. of positive & \% positive \\
\hline Kafr- El shick & 120 & 18 & 15 \\
\hline Qualyobia & 120 & 6 & 5 \\
\hline Total & 240 & 24 & 10 \\
\hline
\end{tabular}

Table (2): The effect of location on the mean and standard error of brucellosis antibodies in cattle serum samples:

\begin{tabular}{|c|c|}
\hline Locations & Mean \pm SE of brucellosis antibodies \\
\hline Kafr- El Shick & $1.15^{\mathrm{a}} \pm 0.03$ \\
\hline Qualyobia & $1.05^{\mathrm{b}} \pm 0.02$ \\
\hline
\end{tabular}

- The mean with different superscript in the same column are significantly different.

- The significant difference at the 0.05 level.

- The confidence interval for mean equal $95 \%$

Table (3): Seroprevallence of brucellosis among cattle sera in relation to age at Kafr- EL Shick and Qualyobia

\begin{tabular}{|c|c|c|c|c|}
\hline \multicolumn{5}{|c|}{ farms } \\
\hline Governorates & Age & No. of samples & No. of positive & \% positive \\
\hline \multirow{3}{*}{ Kafr- El shick } & $\leq 1.5 \mathrm{ys}$ & 15 & 0 & 0 \\
\cline { 2 - 5 } & $1.5-6 \mathrm{ys}$ & 48 & 3 & 6.25 \\
\cline { 2 - 5 } & $>6 \mathrm{ys}$ & 57 & 15 & 0 \\
\hline \multirow{3}{*}{ Qualyobia } & $\leq 1.5 \mathrm{ys}$ & 15 & 0 & 0 \\
\cline { 2 - 5 } & $1.5-6 \mathrm{ys}$ & 78 & 6 & 22.2 \\
\cline { 2 - 5 } & $>6 \mathrm{ys}$ & 27 & 24 & 10 \\
\hline Total & - & 240 & 0 & 0 \\
\hline
\end{tabular}

Table (4): The effect of age on the mean and standard error of brucellosis antibodies in cattle serum samples

\begin{tabular}{|c|c|c|}
\hline \multirow{2}{*}{ Age } & \multicolumn{2}{|c|}{ Mean \pm SE of brucellosis antibodies } \\
\cline { 2 - 3 } & Kafr- El Shick & Qualyobia \\
\hline$\leq 1.5$ years & $1.00^{\mathrm{b}} \pm 0.00$ & $1.00^{\mathrm{b}} \pm 0.00$ \\
\hline $1.5-6$ years & $1.06^{\mathrm{b}} \pm 0.03$ & $1.00^{\mathrm{b}} \pm 0.00$ \\
\hline$>6$ years & $1.26^{\mathrm{a}} \pm 0.05$ & $1.22^{\mathrm{a}} \pm 0.08$ \\
\hline
\end{tabular}

- The mean with different superscript in the same column are significantly different.

- The significant difference at the 0.05 level.

- $\quad$ The confidence interval for mean equal 95 
Table (5): Some serum biochemical parameters (Mean \pm SE) in control and brucella infected groups

\begin{tabular}{|c|c|c|}
\hline Biochemical parameters & Healthy cows & $\begin{array}{c}\text { Cows with } \\
\text { Brucella infection }\end{array}$ \\
\hline $\begin{array}{c}\text { ALT } \\
\text { (U/L) }\end{array}$ & $38.11 \pm 7.64^{\mathrm{a}}$ & $97.25 \pm 17.25^{\mathrm{b}}$ \\
\hline $\begin{array}{c}\text { AST } \\
\text { (U/L) }\end{array}$ & $80.0 \pm 3.18^{\mathrm{a}}$ & $229.0 \pm 26.50^{\mathrm{b}}$ \\
\hline $\begin{array}{c}\text { CK } \\
\text { (U/L) }\end{array}$ & $66.60 \pm 3.17^{\mathrm{a}}$ & $94.50 \pm 0.50^{\mathrm{b}}$ \\
\hline CRP & $8.41 \pm 1.30^{\mathrm{a}}$ & $11.30 \pm 2.33^{\mathrm{a}}$ \\
\hline $\begin{array}{c}\text { Cholesterol } \\
\text { (mg/dl) }\end{array}$ & $93.80 \pm 5.87^{\mathrm{a}}$ & $124.13 \pm 8.13^{\mathrm{b}}$ \\
\hline $\begin{array}{c}\text { Urea } \\
\text { (mg/dl) }\end{array}$ & $25.82 \pm 1.15^{\mathrm{a}}$ & $25.78 \pm 1.77^{\mathrm{a}}$ \\
\hline $\begin{array}{c}\text { Creatinine } \\
(\mathrm{mg} / \mathrm{dl})\end{array}$ & $0.82 \pm 0.02^{\mathrm{a}}$ & $0.85 \pm 0.31^{\mathrm{a}}$ \\
\hline $\begin{array}{c}\text { Glucose } \\
\text { (mg/dl) }\end{array}$ & $101.73 \pm 6.07^{\mathrm{a}}$ & $102.22 \pm 6.51^{\mathrm{a}}$ \\
\hline
\end{tabular}

Means in the same row with different superscript letters are significantly different at $\mathrm{p}<0.05$

\section{Discussion}

Brucellosis is one of the most serious animal and human diseases. It is a zoonotic infectious disease and can affect the economy of a country by inflecting heavy loss to the livestock and dairy industries [30]. Health surveillance is the ongoing systemic collection, analysis and interpretation of health data essential for planning, implementing and evaluating public health activities. The scope of surveillance is broad from early warning systems for rabid response in the case of communicable and highly infectious disease [31]. Egypt is one endemic area as reported from retrospective study. Mainly governorates in Egypt suffering from brucellosis outbreaks.

The viability of brucella microorganism outside the animal host influenced by the prevailing environmental conditions. From the retrospective study, brucellosis outbreaks were higher in Kafr- El Shick than Qualyobia governorates during last six years. Also the mean value of brucellosis was the highest in winter season all over the governorates were infected by brucellosis during the last six years. This indicate the viability of brucella microorganism is enhanced by cool temperatures and moisture than high temperature $\left(45\right.$ to $\left.50{ }^{\circ} \mathrm{c}\right)$ survival time is short about $4 \mathrm{hrs}$ but a lower temperature $\left(15^{\circ} \mathrm{c}\right)$ survival time at least 8 months [32]. This lead to the conclusion of the importance of surveillance to detect the epidemiology of the disease.

The incidence of brucella antibodies was higher in Kafr- El Shick than Qualyobia governorate may be attributed to the lower temperature and higher moisture in Kafr- El Shick than Qualyobia due to geographical, environmental and agriculture condition of kafr- El Shick. There were highly significant correlation between mean value of brucellosis antibodies with different localities and housing system where blood samples were collected. There is direct relationship between herd size and probability of herd brucellosis in dairy cattle. The larger populations often have a greater density which results in an increase in potential for exposure to infection. The degree of shedding from infected animals is the most critical factor. Large herds of livestock are more likely to import replacement animals which increase the probability of introducing those which may be incubating the disease [33].

There was a statistically difference between young and adult cattle. The highest brucellosis antibodies were detected in cattle serum samples $>6$ years of age this may be attributed to the fact sex hormones and erythritol that stimulate multiplication of brucella organisms, tend to increase in concentration with age and sexual maturity [34]. Regarding the liver function enzymes, we found that there are significant increases in ALT and AST levels in Brucella infected cows when compared with healthy cows indicating severe damage in the liver. These results are in compliance with the results of [35], [36], [37], [13].and [38]. The obtained results may be attributed to that the predilection organs for Brucella organism are rich in reticuloendothelial cells (spleen, liver, bone marrow and lymph node) [39]. Due to the liver is the largest organ of the reticuloendothelial system and plays the important role of defense mechanism against Brucella infections, diffuse hepatic involvement is usually reported during the course of Brucella infection [40]. The results of the present study showed significant increase in CK level in brucella infected cows when compared with healthy cows. Similar results were reported previously [38]. [41] reported different forms of endometeritis, ulcerative, granulomatis, hemorrhagic and chronic during histopathological examination of uterus of cows infected with brucella. Moreover, [42] founded that cows with pathological uterine findings (clinical endometeritis) have elevated CK and AST activities in serum that correlated significantly with the degree of endometeritis.

Serum cholesterol concentration showed significant increase in Brucella infected cows in comparison with healthy cows. This results agreed with that of [43] who indicated that brucella infection increase serum total cholesterol, LDL-cholesterol and high level of LDL/HDL ratio in brucella infected animals. The increase 
in the serum cholesterol concentration may be attributed to hepatic damage. Normal metabolizing activity and excretory as bile acids of liver gets hampered so the cholesterol accumulated [13]. Or may be attributed to reduced lipoprotein lipase enzyme activity. [44] reported that Brucella abortus is a gram- negative intracellular bacterium; it induces the production of tumor necrosis factor $(\mathrm{TNF} \alpha)$. The production of $\mathrm{TNF} \alpha$ inhibits lipoprotein lipase enzyme [45].

There were no significant changes in urea, creatinine, glucose and CRP levels in cows infected with Brucella when compared with healthy cows. [46] found no significant changes in serum creatinine level in Brucella infected cows. Also, [37] reported no significant changes in glucose level in brucella infected cows. On the other hand, [47] and [13] reported significant increase in creatinine level in brucella infected cattle and significant decrease in glucose level in brucella infected ewes respectively. Also, [36] found a significant correlation between CRP level and antibodies titre in patients infected with brucella. The variation may be due to severity of brucellosis or may be due to difference of animal species. [14] mentioned that brucella species infect vital organs of the body leading to their function impairment. This function impairment depends on the stage of brucellosis and extent of organ's damage.

\section{Conclusion}

From the present study, Egypt is endemic area with brucellosis so, implement the periodic seroprevalence studies in the susceptible animal for early diagnosis of brucella infection which, it is a good tool for eradication of brucellosis. brucella infection has degenerative effect on liver. Study of biochemical parameters can determine the extent of hepatic damage caused by brucellosis.

\section{Reference}

[1]. S.J. Cutler and R.R.Cutler, Brucellosis, the most common bacterial zoonosis. The Biomedical Scientist, 50. 2006, 336-341

[2]. O.M. Radostits, O. M., C.C. Gay, D.C. Blood and K. W. Hinchcliff, Veterinary medicinem, ${ }^{\text {th }}$ Ed., ELBS Bailliere Tindall, London, UK, 2000, pp: 870-871.

[3]. T. England, L. Kelly, R.D. Jones, A. MacMillan and M. Wooldridge, A simulation model of brucellosis spread in British cattle under several testing regimes. Prev Vet Med 63, 2004, 63-73.

[4]. WHO. Technical Report Series, Joint FAO/WHO Expert Committee in Brucellosis, 5th Report, $1971,464$.

[5]. G. Oktay, O. Salih and S. Mitat, Seroprevalence of Brucellosis and Leptospirosis in Aborted Dairy Cows. Turk J Vet Anim Sci 29, 2005, 359-366.

[6]. B. Garin-Bastuji, J.M. Blasco, C. Marin and D. Albert, The diagnosis of brucellosis in sheep and goats, old and new tools. Small Ruminant Research 62, 2006, 63-70.

[7]. D.C. Blood, O.M. Radostits and J.A. Henderson, Veterinary Medicine (6th ed.).1986, Philadelphia: Bailliere Tindall.

[8]. T.G. Hungerford, Diseases of Livestock. 9th ed., McGraw-Hill Book Company, Sydney. 1990, $1302-1304$.

[9]. M. Refai, Incidence and control of brucellosis in the near East region. Vet Microbiol. 90, 2002, 81-110.

[10]. J. Godfroid, K. Nielsen and C. Saegerman, Diagnosis of brucellosis in livestock and wildlife. Croat Med J 51, 2010, 296-305.

[11]. E.J.Young. Brucella species.In: Mandell GL, Bennet JE, Dolin R, editors.Principles and Practice of Infectious Diseases. 5th ed. Philadelphia: Churchill Living-stone. 2000, 2386-2393.

[12]. I. Altuglu, A. Zeytinoglu, A. Bilgic, S. Kamcioglu, G. Karakartal and H. Smits, Evaluation of brucella dipstick assay for the diagnosis of acute brucellosis. Diagn Microbiol Infect Dis 44, 2002, 241-243.

[13]. A. Kumar, N. Srikanth, G. Naresh and B. Vidya, Assessment and comparison of serum biochemical parameters of Brucella infected and healthy ewes. J Livestock Sci 6, 2015, 100-103.

[14]. O.M. Radostits, C.C. Gay, K.W. Hinchcliff and P.D. Constable. Veterinary Medicine: A textbook of the diseases of cattle, horse, sheep, pigs \&goat. Saunders. 26, 2007, 1518-1522.

[15]. A.M. Al-Majali, Seroepidemiology of caprine Brucellosis in Jordan. Small Rumin Res 58, 2005, 13-18

[16]. D.W. Moss and A.R. Henderson, Clinical enzymology. In C. A. Burtis \& E. R. Ashwood (Eds.), Tietz-Textbook of Clinical Chemistry . USA: W.B.Sounders Co., 1999, 617-721.

[17]. H.D. Mahboub, M.A. Helal, M.A. Abd Eldaim, E.M. Abd El-Razek and A.M. Elsify, Seroprevalence of Abortion Causing Agents in Egyptian Sheep and Goat Breeds and Their Effects on the Animal's Performance. Journal of Agricultural Science 5, 2013, 92101.

[18]. I.A. Yagoub, A.A. Mohamed and M.O. Salim, Serological survey of Brucella abortus antibody prevalence in the one-humped camel (Camelus dromedarius) from eastern Sudan. Revue D'elevage et de Medecine Veterinaire des Pays Tropicaux 43, $1990,167-171$.

[19]. OIE, Bovine brucellosis. Section 23 in OIE manual of Standards for disgnostic tests and vaccines. 2015.

[20]. W.J.B. Morgan, D.J. Mackinnon and G.A. Cuullen, The Rose Bengal Plate Agglutination test in the diagnosis of brucellosis. Vet $\operatorname{Rec} 85,1969,636$

[21]. R.D. Angus and C.E. Barton, The production and evaluation of a buffered plate antigen for use in a presumptive test for brucellosis develop. Bio Standard 56, 1984, 349-356.

[22]. G.G. Alton, L.M. Jones, R.D. Anus and J.M. Verger, Techniques for the brucellosis laboratory. INRA, Paris ISEN.1988.

[23]. S. Reitman and S. Frankel, Colorimetric method for determination of oxaloacetic transaminase. Am J Clin 28, 1957, 56-56.

[24]. R.J. Henry. Clinical chemistry, principles and technics, $2^{\text {nd }}$ Ed. Harper and Row,1974, 525.

[25]. C.J. Patton and S.R. Crouch, Spectrophotometric and kinetics investigation of the Berthelot reaction for the determination of ammonia. Anal Chem 49,1977, 464-469.

[26]. H.V. Bergmeyer, Determination of serum glucose. Verlag Chemic. Associate press, New York, $1974,1196$.

[27]. Flegg, H.M, Quantitative enzymatic colorimetric determination of total and HDL-C in serum or plasma. Ann. Clin. Biochem, 1973, 10: 79 .

[28]. B. Abbot, Creatinine kinase Clin. Chem.the C.V, Mosby Co.St Louis. Toronto.Princeton.1984, $1112-1116$.

[29]. M.M. Kimberly, H.W. Vesper, S.P. Caudill, G.R. Cooper, R. Nader, F. Dati and G.L. Myers, Standerdization of immunoassays for measurement of high sensitivity C- ractive protein phase 1: Evaluation of secondary reference material. Clin Chem 49, 2003, 611616. 
[30]. M. Ghani, M.Z. Siraj and M. Naeem, Sero- Epidemiological study of brucellosis among goats and sheep at Peshawar (district). AJAS 8, 1990, 489-494.

[31]. WHO, Basic epidemiology $2^{\text {nd }}$ edition, 2006.

[32]. K. Nielsen and J. R. Duncan, Animal brucellosis, 1990

[33]. M.M. Monir, Brucellosis book.2014.

[34]. A.A. Justine, E.M. Lucas, K.M.Shabani, J.M. Joseph and R.K. Rudovick, Epidemiology of brucella infection in the human, livestock and wildlife interface in the Katavi-Rulcwa ecosystem, Tanzania. BMC Vet Res 11, 2015, 189.

[35]. M. El-Boshy, H. Abbas, S. El-Khodery, and S. Osman, Cytokine response and clinicopathological findings in Brucella infected camels (Camelus dromedarius). Veterinarni Medicina 54, 2009, 25-32.

[36]. A, Harunn and E. Gülin, The Relationship between Standard Tube Agglutination Titers in Brucellosis And Biochemical and Hematologic Parameters. J Clin Anal Med.3(4), 2012, 432-4

[37]. N. Rita, D. Sutopa, S. Satya, and D. Maitrayee, Comparison of blood profiles between healthy and Brucella affected cattle. Veterinary World 7, 2014, 668-670.

[38]. M. Abou-elAzab, Evaluation of serum enzyme activities and protein fractions in Brucella-infected cows. Turk J Vet Anim Sci 39, 2015, 480-484.

[39]. M.N. Seleem, S.M. Boyle, N. Sriranganathan, Brucellosis: a re-emerging zoonosis. Vet Microbiol. 140(3-4), $2010,392-8$.

[40]. J. Ariza, C. Pigrau, C. Canas, A. Marron, F. Martinez, B. Almirante, J. Corredoira, A. Casanova, J. Fabregat and A, Pahissa, Current understanding and management of chronic hepatosplenic suppurative brucellosis. Clin Infect Dis 32, $2001,1024-1033$.

[41]. Y.F. Ahmed, Sohair, M. Sokkar, H.M. Desouky and A.A. Madbouly, Pathological Studies on Buffalo-Cows Naturally Infected with Brucella melitensis. Global Veterinaria 9 (6), 2012, 663-668.

[42]. T. Sattler and M. Furll, Creatine Kinase and Aspartate Aminotransferase in Cows as Indicators for Endometritis. J Vet Med 51, 2004, 132-137.

[43]. A.A. AL-Naqshabendy, A.A. Iberahiem and O.H. Azeez, Effect of Brucella melitensis on the serum lipids profiles in ewes. Assiut Vet Med J 60 (142), 2014, 156-159.

[44]. W. Bruce, H. Tajie, Q. Nilofer and A. Gary, Splitter Rough Lipopolysaccharide from Brucella abortus and Escherichia coli. Differentially Activates the Same Mitogen-Activated Protein Kinase Signaling Pathways for Tumor Necrosis Factor Alpha in RAW 264.7 Macrophage-Like Cells. Infect. Immunity 70, 2002, 7165-7168.

[45]. C. Creput, L. Galier, E.H. Oksen, and E. Azoulay, Pathphysiology of organ dysfunction in the macrophage activation syndrome. Reanimation 14, 2005, 604-613.

[46]. N. Bouhroum, B. Bensahli and A. Niar, Evolution of biochemical parameters in post partum cows affected with brucella, in the wilay a of Relizane. African Journal of Biotechnology 11, 2012, 1818-1822.

[47]. N. Kushwaha, V.S.Rajora, A.Mohan, J.L.Singh, S.K. Shukla, Assessment of Haemato-biochemical Parameters and Therapeutics on Brucella Infected Cattle. J Microbiol Exp 1(2),2014,00012. 